\title{
Article \\ Virulence Structure of the Wheat Powdery Mildew Population in Serbia
}

\author{
Mirjana Lalošević ${ }^{1, *(\mathbb{D})}$, Radivoje Jevtićc ${ }^{1, *(\mathbb{D})}$, Vesna Župunski ${ }^{1}$ (), Stevan Maširević ${ }^{2}$ and Branka Orbović $^{1}$ \\ 1 Institute of Field and Vegetable Crops, Maksima Gorkog 30, 21000 Novi Sad, Serbia; \\ vesna.zupunski@ifvcns.ns.ac.rs (V.Ž.); branka.orbovic@ifvcns.ns.ac.rs (B.O.) \\ 2 Faculty of Agriculture, University of Novi Sad, Trg Dositeja Obradovića 8, 21000 Novi Sad, Serbia; \\ stevanmasirevic5@gmail.com \\ * Correspondence: mirjana.lalosevic@ifvcns.ns.ac.rs (M.L.); radivoje.jevtic@ifvcns.ns.ac.rs (R.J.)
}

check for updates

Citation: Lalošević, M.; Jevtić, R.; Župunski, V.; Maširević, S.; Orbović, B. Virulence Structure of the Wheat Powdery Mildew Population in Serbia. Agronomy 2022, 12, 45. https://doi.org/10.3390/ agronomy12010045

Academic Editors: Diego Rubiales and Jerzy Henryk Czembor

Received: 30 October 2021

Accepted: 21 December 2021

Published: 25 December 2021

Publisher's Note: MDPI stays neutral with regard to jurisdictional claims in published maps and institutional affiliations.

Copyright: (C) 2021 by the authors. Licensee MDPI, Basel, Switzerland. This article is an open access article distributed under the terms and conditions of the Creative Commons Attribution (CC BY) license (https:// creativecommons.org/licenses/by/ $4.0 /)$

\begin{abstract}
Powdery mildew is a common, economically important disease in the wheat growing area of Serbia. A large-scale virulence survey of its causal agent Blumeria graminis f. sp. tritici population was performed in the period 1995-2013. A total of 1013 isolates were recovered from the collected chasmothecial samples. Among them, 862 unique pathotypes were identified using a differential set of 20 wheat lines with known powdery mildew $(P m)$ resistant genes. The pathogen was highly diverse. Number of virulence genes (virulence complexity) per isolate was large, supporting a constant need to extend the differential set of wheat with newly identified $P m$ genes. Virulence frequencies to $P m 6, P m 7$, and $P m 5+8$ were high throughout the 19-year period, in contrast with that to $P m 5+6$, which was consistently at a low level. The most significant change in the population was observed for virulence to the $P m 2+4 b+6$ gene combination, with an increasing frequency of virulence to this gene combination over the years. High virulence complexity and genetic diversity of the population are the most influential factors for the damaging epidemics that this pathogen can cause.
\end{abstract}

Keywords: Blumeria graminis f. sp. tritici; population; virulence analysis

\section{Introduction}

Wheat powdery mildew, caused by Blumeria graminis f. sp. tritici, is a common disease in wheat growing areas worldwide. It can cause significant yield and quality losses. The disease occurs every year at a lower or higher intensity in Serbia, reducing yield on average by $30 \%$ on susceptible cultivars [1].

B. graminis $\mathrm{f}$. $\mathrm{sp}$. tritici is an obligate, biotrophic fungal pathogen, with a mixed mode of reproduction (sexual and asexual). In Serbia, sexual reproduction occurs in late spring (prior to wheat senescence) by producing chasmothecia. This fruiting body is a means of pathogen survival of unsuitable summer conditions, and also a source of sexual recombination. By maturing, the chasmothecia ascospores may be released and act as a primary source of inoculum for new infections in late spring or early summer. Initial infections are followed by multiple cycles of asexual reproduction. The number of these cycles depends on weather conditions.

Mc Donald and Linde [2] reported B. graminis f. sp. tritici as a high-risk pathogen due to its high adaptability and changeability potential. For these reasons, breeding for resistance to powdery mildew is a difficult and laborious task.

One of the main preconditions for successful wheat production is effective powdery mildew control. This can be achieved by fungicide treatment, and by sowing resistant varieties. Unfortunately, there are limited data about powdery mildew resistance genes $(P m)$ in the commercial wheat varieties grown in Serbia. Monitoring the virulence structure and diversity of wheat powdery mildew populations is important and necessary in order to identify efficient host resistant genes, as well as to track virulence changes in the pathogen population. These data enable breeders to prioritize $\mathrm{Pm}$ genes for utilization in wheat lines [3]. 
Annual virulence surveys of $B$. graminis $\mathrm{f}$. sp. tritici populations have been conducted in Serbia since 1961 [4]. In the first period, physiological races were determined based on reactions of a few standard wheat varieties. However, since the mid 1980s, determining the virulence pathotypes on the basis of genetic background of differential wheat lines has been introduced as a more appropriate approach. The most frequent virulence genes in the late 1980s were genes virulent to Pm1, Pm2, Pm3a, Pm5, Pm6, and Pm8 [5]. The most efficient $P m$ genes in 1991-1992 were Pm4a,Pm4b, Mld, and the combinations Pm5+6 and Pm2+4b+6 [6].

Long-term studies of the powdery mildew population are aimed at revealing shifts in virulence frequencies that lead to changes in the virulence structure of the pathogen population.

The present study includes data from virulence surveys of B. graminis f. sp. tritici in Serbia during the period 1995-2013. It has been hypothesized that changing efficacy of $\mathrm{Pm}$ genes would result in shifts in the powdery mildew population. Therefore, the objective of this study was to determine and characterize the virulence structure of the B. graminis $\mathrm{f}$. $\mathrm{sp}$. tritici population in Serbia. The results would give insight into the dynamics of the powdery mildew population and contribute to a better understanding of its pathogenicity potential.

\section{Materials and Methods}

\subsection{Collection and Preparation of Isolates}

Senescent wheat leaf samples bearing chasmothecia of the powdery mildew pathogen (B. graminis f. sp. tritici) were collected from wheat fields at 83 locations in Serbia from 1995 to 2013. The number of randomly sampled leaves varied depending on the infection, but was at least 10 leaves per field.

Leaf samples with disease symptoms were placed separately in a clean paper bag and stored at $4{ }^{\circ} \mathrm{C}$ until they were used in the experiments. Powdery mildew susceptible wheat variety Barbee was used for the isolation, purification, multiplication, and maintenance of the isolates. The seeds of this variety were sown in $10 \times 10 \mathrm{~cm}$ clay pots filled with commercial potting mix. Seedlings were grown in a growth chamber at $20^{\circ} \mathrm{C}$ and $12 \mathrm{~h}$ of light. In order to obtain isolates, 200 chasmothecia from each leaf sample were collected with a sterile needle and placed on moist filter paper inside the lid of a Petri dish. When seedlings were at the second leaf stage, the Petri dish lid was placed on the top of the seedlings. The filter paper was moistened daily. The colonies of powdery mildew developed after 7 to 8 days. A single pustule from each isolate was transferred to the leaves of the susceptible variety Barbee using a dissecting needle. The inoculum multiplication was performed by shaking infected leaves to 7-day-old seedlings (1-2 leaf stage).

\subsection{Virulence Analysis}

Virulence of each single-pustule isolate was assessed by inoculation of a differential set of 20 wheat lines bearing different $P m$ genes or combinations of $P m$ genes (Table 1). The differential set was sown in plastic trays filled with commercial potting mix in four replicates. Seedlings were grown in greenhouse conditions at $20{ }^{\circ} \mathrm{C}$ with $12 \mathrm{~h}$ of light, covered with plastic cylinders to avoid contamination. When seedlings developed the second leaf (7-8 days from seeding), they were inoculated by gently shaking conidia from 2-week-old isolates.

The reaction type was assessed on each differential line 7 days after inoculation using the modified scale of Mains [7], as follows: $0=$ no visible symptoms; 1 = highly resistant, fungal development limited, necrosis, no sporulation; 2 = moderately resistant, moderate mycelium with some sporulation; 3 = moderately susceptible, extensive mycelium, more sporulation; 4 = highly susceptible, abundant sporulation, large colonies.

\subsection{Data Analysis}

Virulence genes of each powdery mildew isolate were determined based on the reaction of each differential line according to Flor's gene for gene hypothesis [8]. If reaction type on the differential line was scored 0-2 or 3-4, such isolate was classified as avirulent or 
virulent, respectively, to the corresponding Pm gene or combination of Pm genes. Accordingly, a binary virulence profile was postulated for each powdery mildew isolate, where 1 and 0 encoded virulence and avirulence.

Table 1. Host differentials and genes used in virulence tests of Blumeria graminis f. sp. tritici isolates.

\begin{tabular}{|c|c|c|}
\hline Pm Gene & Host Differential & Accession Number \\
\hline$P m 1 a$ & Axminster $/ 8^{*}$ Chancellor & CI 14114 \\
\hline Pm2 & Ulka $/ 8^{*}$ Chancellor & CI 14118 \\
\hline $\operatorname{Pm} 2+$ & Idaed 59B $/ 8^{*}$ Chancellor & CI 14119 \\
\hline$P m 3 a$ & Asosan $/ 8^{*}$ Chancellor & CI 14120 \\
\hline$P m 3 b$ & Chul/8*Chancellor & CI 14121 \\
\hline$P m 3 c$ & Sonora $/ 8^{*}$ Chancellor & CI 14122 \\
\hline $\mathrm{Pm} 4 a$ & Khapli/ $8^{*}$ Chancellor & CI 14123 \\
\hline$P m 4 b$ & Weihenstephan M-1 & $\mathrm{NIC}^{1}$ \\
\hline Pm5 & Hope $/ 8^{*}$ Chancellor & CI 14125 \\
\hline Pm6 & Coker 747 & NIC \\
\hline $\operatorname{Pm} 7$ & Transec & CI 14189 \\
\hline Pm8 & Kavkaz & CI 361879 \\
\hline $\operatorname{Pm17}$ & Amigo & CI 17609 \\
\hline$P m 1+2+9$ & Normandie & NIC \\
\hline$P m 2+6$ & CI 12633 & CI 12633 \\
\hline$P m 5+6$ & Coker 983 & NIC \\
\hline Mld & Halle Stamm 13471 & $\mathrm{NIC}$ \\
\hline$P m 5+8$ & Granada & $\mathrm{NIC}$ \\
\hline Mli & Dolomit & $\mathrm{NIC}$ \\
\hline$P m 2+4 b+6$ & C39 & NIC \\
\hline
\end{tabular}

$1-\mathrm{NIC}=$ not in the collection.

Individual pathotypes of the powdery mildew isolates were assigned using a hexadecimal code as follows: the set of 20 differentials was divided into five groups of four consecutive differentials each. Then binary patterns of individuals were represented by the ordered sets of five $\{0,1\}$-four-tuples (four-tuple means four ordered symbols) according to the division of differentials into groups. Accordingly, each four-tuple could be encoded by a single letter from a set of the first 20 consonants of the English alphabet [9].

Several descriptive parameters were calculated for each annual population of B. graminis f. sp. tritici: number of pathotypes, singletons, virulence frequencies, and (relative) virulence complexity. Virulence frequencies are presented by the proportion of the virulence gene in each year. Virulence complexity of each isolate equals the number of susceptible differentials to the given isolate and thus ranges from 1 to 20 , while the relative virulence complexity values ranges from 0 to 1 . The corresponding average value per isolate in a population was considered (relative) virulence complexity of the population.

Diversity within populations was measured using Simpson's index and Kosman KW metric with regard to the simple mismatch dissimilarity codes [10]. Pairwise distance between populations was estimated using Rogers and Nei's standard genetic distance [11]. Coefficient of association $\varphi$ between pairs of differentiating characters was determined by formula 17.5 in [12] related to Fisher's exact test. In addition, the measure of correlation between pairs of differentials was also estimated (formula 1 [13]). All calculations were performed with the VIRULENCE ANALYSIS TOOL (VAT) software [14].

According to the calculated frequencies, virulence genes were categorized into three classes: (1) genes with null or low frequencies ( $\leq 20 \%)$; (2) genes with intermediate frequencies (between 20\% and 50\%), and (3) genes with high frequencies ( $>50 \%$ ) [15].

Relationships among powdery mildew populations was analyzed using the unweighted pair group method with arithmetic means (UPGMA) with the matrix of Nei's standard genetic distances. The UPGMA clustering was performed using NTSYS-pc software [16]. 


\section{Results}

\subsection{Pathotypes Structure}

A total of 1013 B. graminis f. sp. tritici isolates were recovered from the chasmothecial samples collected from 1995 to 2013 (Table 2). Among them, 862 distinct pathotypes were identified. In 1997, 2001, 2004, and the period 2006-2010, all isolates of each annual collections were of different pathotype (singletons). Only 108 pathotypes were identified more than once in the population. Certain consistency regarding the most frequent pathotypes in the population of $B$. graminis $\mathrm{f}$. sp. tritici for the given period was observed. The most frequent pathotypes were TTTSJ (virulence to Pm1,Pm 2,Pm2+,Pm3a,Pm3b, Pm3c, Pm4a, Pm4b, Pm5, Pm6, Pm7, Pm8, Pm17, Pm1+2+9, Pm2+6, Pm5+8, Mli) during the period 1995-2003, and GDQBC (virulence to Pm2,Pm4a,Pm5,Pm6, Pm2+4b+6) in the last 3 years of the survey (Table 3). The most frequent group of pathotypes was that encoded TTT ${ }^{* *}$ characterized by virulence to Pm1, Pm2, Pm2+, Pm3a, Pm3b, Pm3c, Pm4a, Pm4b, Pm5, Pm6, Pm7, Pm8, Pm17, and Pm1+2+9.

Table 2. Response of the Blumeria graminis f. sp. tritici isolates on wheat differentials during 1995-2013.

\begin{tabular}{cccccc}
\hline Year & $\begin{array}{c}\text { No of } \\
\text { Isolates }\end{array}$ & $\begin{array}{c}\text { No of Pathotypes } \\
\text { with (without) Singletons }\end{array}$ & $\begin{array}{c}\text { Simpson's } \\
\text { Index }\end{array}$ & $\begin{array}{c}\text { Kosman } \\
\text { Index }\end{array}$ & $\begin{array}{c}\text { Average of Relative } \\
\text { Complexity }\end{array}$ \\
\hline 1995 & 156 & $91(21)$ & 0.965 & 0.360 & 0.72 \\
1996 & 126 & $103(12)$ & 0.986 & 0.428 & 0.63 \\
1997 & 59 & $59(0)$ & 0.983 & 0.480 & 0.50 \\
1998 & 190 & $177(11)$ & 0.994 & 0.471 & 0.60 \\
1999 & 84 & $66(14)$ & 0.981 & 0.336 & 0.64 \\
2000 & 40 & $22(6)$ & 0.909 & 0.170 & 0.81 \\
2001 & 12 & $12(0)$ & 0.917 & 0.417 & 0.21 \\
2002 & 52 & $51(1)$ & 0.980 & 0.498 & 0.59 \\
2003 & 48 & $46(2)$ & 0.977 & 0.481 & 0.62 \\
2004 & 8 & $8(0)$ & 0.875 & 0.425 & 0.38 \\
2005 & 36 & $35(1)$ & 0.971 & 0.703 & 0.49 \\
2006 & 20 & $20(0)$ & 0.950 & 0.355 & 0.57 \\
2007 & 16 & $16(0)$ & 0.938 & 0.444 & 0.47 \\
2008 & 16 & $16(0)$ & 0.938 & 0.394 & 0.51 \\
2009 & 40 & $40(0)$ & 0.975 & 0.383 & 0.63 \\
2010 & 29 & $29(0)$ & 0.966 & 0.607 & 0.45 \\
2011 & 25 & $20(4)$ & 0.941 & 0.528 & 0.47 \\
2012 & 28 & $25(2)$ & 0.954 & 0.600 & 0.50 \\
2013 & 28 & $26(2)$ & 0.959 & 0.514 & 0.41 \\
Total & 1013 & 862 & & & 0.54 \\
\hline
\end{tabular}

Table 3. The most frequent pathotypes of Blumeria graminis f. sp. tritici collected during 1995-2013.

\begin{tabular}{cccc}
\hline Year & $\begin{array}{c}\text { Most Frequent Pathotypes } \\
\text { (Hexadecimal Codes) }\end{array}$ & Frequency (\%) & $\begin{array}{c}\text { Relative Virulence } \\
\text { Complexity }\end{array}$ \\
\hline \multirow{2}{*}{1995} & TTTSJ & 11 & 0.85 \\
& TTTSS & 11 & 0.90 \\
\hline \multirow{2}{*}{1996} & TTTSJ & 5.6 & 0.85 \\
& TTTSK & 4.8 & 0.90 \\
\hline \multirow{2}{*}{1997} & - & - & - \\
\hline \multirow{2}{*}{1998} & TTTSJ & 1.6 & 0.85 \\
& TGTQS & 1.6 & 0.70 \\
\hline \multirow{2}{*}{1999} & TGKLJ & 4.8 & 0.55 \\
& TGTDJ & 4.8 & 0.60 \\
\hline
\end{tabular}


Table 3. Cont.

\begin{tabular}{cccc}
\hline Year & $\begin{array}{c}\text { Most Frequent Pathotypes } \\
\text { (Hexadecimal Codes) }\end{array}$ & Frequency (\%) & $\begin{array}{c}\text { Relative Virulence } \\
\text { Complexity }\end{array}$ \\
\hline 2000 & TTTSJ & 22.5 & 0.85 \\
\hline 2001 & -1 & - & - \\
\hline 2002 & TTTSS & 3.8 & 0.90 \\
\hline 2003 & TTTSJ & 4.2 & 0.85 \\
& FKTLK & 4.2 & 0.65 \\
\hline 2004 & - & - & - \\
\hline 2005 & TTTTT & 5.6 & - \\
\hline 2006 & - & - & - \\
\hline 2007 & - & - & - \\
\hline 2008 & - & - & - \\
\hline 2009 & - & - & 0.25 \\
\hline 2010 & - & - & 0.25 \\
\hline 2011 & GDQBC & 12.0 & 0.25 \\
\hline 2012 & GDQBC & 10.7 & 0.05 \\
\hline \multirow{2}{*}{2013} & GDQBC & 7.1 & 0.85 \\
& BBGBB & 7.1 & 0.90 \\
\hline & TTTSJ & 3.94 & 0.85 \\
\hline & TTTSS & 1.25 & -1.39 \\
\hline
\end{tabular}

1_All isolates are of unique virulence phenotype.

Virulence complexity of the most frequent pathotypes during 1995-2003 ranged from 0.55 to 0.90 and was much higher than that of the most frequent pathotype GDQBC in 2011-2013 with complexity 0.25 .

\subsection{Virulence Frequencies and Associations between Virulence Genes}

Virulence frequencies of B. graminis f. sp. tritici genes in the period 1995-2013 are given in Tables 4 and 5 . The most frequent virulences during the whole period were those to Pm6 and Pm7. Virulences to these genes were constantly high, except in 2001 when virulence to all genes had low or intermediate frequencies. The greatest shift of virulence was observed for the virulence to the gene combination Pm2 $+4 b+6$ (Figure 1).

Pairwise virulence associations were revealed within annual populations of wheat powdery mildew, though many of them were detected only once. Associations between virulences to $P m 2$ and $P m 2+, P m 3 a$ and $P m 3 b$, and $P m 3 b$ and $P m 4 b$ were observed at least in five annual populations. Pairwise association between virulences to $P m 3 b$ and $P m 4 b$ was consistent in the last 5 years of the survey. Association of virulences to Mli and Pm2+4b+6 was found in 2004, 2005, and during the period 2010-2013.

\subsection{Diversity within Populations}

The Simpson's index of diversity within population (Table 2), ranging from 0.87 in 2004 and close to the absolute maximum 1.00 in most years, shows a high phenotypic diversity of the powdery mildew population during 19 years. On the other hand, according to the Kosman index, the highest diversity of 0.703 was in 2005, and the lowest, of 0.17 , was in 2000. High diversity was observed during the last 4 successive years of the survey (2010-2013). 
Table 4. Virulence frequencies of Blumeria graminis f. sp. tritici genes in the period 1995-2003.

\begin{tabular}{|c|c|c|c|c|c|c|c|c|c|}
\hline \multirow{2}{*}{$\begin{array}{l}\text { Resistance } \\
\text { Gene }\end{array}$} & \multicolumn{9}{|c|}{ Virulence Frequency (\%) } \\
\hline & 1995 & 1996 & 1997 & 1998 & 1999 & 2000 & 2001 & 2002 & 2003 \\
\hline$P m 1 a$ & 92.9 & 63.2 & 76.3 & 87.9 & 90.5 & 77.5 & 16.7 & 88.5 & 41.7 \\
\hline Pm2 & 83.3 & 83.20 & 49.2 & 67.9 & 86.9 & 87.5 & 25.0 & 67.3 & 66.7 \\
\hline $\operatorname{Pm} 2+$ & 93.6 & 81.6 & 71.2 & 81.1 & 98.8 & 95.0 & 50.0 & 75.0 & 79.2 \\
\hline$P m 3 a$ & 90.4 & 78.4 & 71.2 & 85.8 & 84.5 & 97.5 & 41.7 & 80.8 & 72.9 \\
\hline$P m 3 b$ & 48.7 & 44.8 & 37.3 & 42.6 & 34.5 & 85.0 & 41.7 & 63.5 & 45.8 \\
\hline$P m 3 c$ & 98.1 & 97.6 & 74.6 & 82.1 & 90.5 & 100.0 & 16.7 & 88.5 & 89.6 \\
\hline$P m 4 a$ & 62.8 & 52.8 & 22.0 & 32.1 & 32.1 & 92.5 & 8.3 & 59.6 & 83.3 \\
\hline$P m 4 b$ & 57.1 & 57.6 & 23.7 & 33.2 & 35.7 & 90.0 & 16.7 & 42.3 & 75.0 \\
\hline Pm5 & 83.3 & 80.0 & 49.2 & 57.4 & 78.6 & 90.0 & 16.7 & 59.6 & 81.3 \\
\hline Pm6 & 87.2 & 95.2 & 79.7 & 91.6 & 98.8 & 97.5 & 41.7 & 92.3 & 89.6 \\
\hline$P m 7$ & 97.4 & 98.4 & 81.4 & 94.7 & 98.8 & 100.0 & 41.7 & 86.5 & 93.8 \\
\hline Pm8 & 93.6 & 95.2 & 64.4 & 93.7 & 89.3 & 97.5 & 8.3 & 80.8 & 64.6 \\
\hline Pm17 & 76.3 & 40.0 & 27.1 & 66.8 & 59.5 & 95.0 & 8.3 & 42.3 & 47.9 \\
\hline$P m 1+2+9$ & 69.9 & 40.8 & 27.1 & 39.5 & 31.0 & 92.5 & 8.3 & 30.8 & 45.8 \\
\hline$P m 2+6$ & 43.6 & 41.6 & 25.4 & 32.1 & 38.1 & 87.5 & 8.3 & 21.2 & 33.3 \\
\hline$P m 5+6$ & 8.3 & 0.0 & 1.7 & 8.9 & 11.9 & 0.0 & 0.0 & 1.9 & 6.3 \\
\hline Mld & 42.9 & 8.0 & 20.3 & 36.8 & 19.0 & 22.5 & 0.0 & 32.7 & 10.4 \\
\hline$P m 5+8$ & 98.7 & 84.0 & 93.2 & 74.2 & 100.0 & 92.5 & 25.0 & 73.1 & 89.6 \\
\hline Mli & 100.0 & 96.8 & 94.9 & 81.1 & 91.7 & 90.0 & 33.3 & 71.2 & 91.7 \\
\hline$P m 2+4 b+6$ & 1.3 & 16.8 & 6.8 & 10.0 & 1.2 & 15.0 & 8.3 & 13.5 & 27.1 \\
\hline
\end{tabular}

Table 5. Virulence frequencies of Blumeria graminis f. sp. tritici genes in the period 2004-2013.

\begin{tabular}{|c|c|c|c|c|c|c|c|c|c|c|}
\hline \multirow{2}{*}{$\begin{array}{c}\text { Resistance } \\
\text { Gene }\end{array}$} & \multicolumn{10}{|c|}{ Virulence Frequency (\%) } \\
\hline & 2004 & 2005 & 2006 & 2007 & 2008 & 2009 & 2010 & 2011 & 2012 & 2013 \\
\hline Pm1a & 0.0 & 47.2 & 75.0 & 31.3 & 31.3 & 57.5 & 55.2 & 60.0 & 50.0 & 28.6 \\
\hline Pm2 & 25.0 & 50.0 & 80.0 & 31.3 & 18.8 & 50.0 & 34.5 & 32.0 & 35.7 & 32.1 \\
\hline$P m 2+$ & 37.5 & 41.7 & 80.0 & 37.5 & 37.5 & 65.0 & 27.6 & 12.0 & 28.6 & 3.6 \\
\hline$P m 3 a$ & 12.5 & 36.1 & 65.0 & 25.0 & 68.8 & 22.5 & 20.7 & 16.0 & 28.6 & 3.6 \\
\hline$P m 3 b$ & 0.0 & 38.9 & 85.0 & 12.5 & 37.5 & 87.5 & 48.3 & 36.0 & 53.6 & 39.3 \\
\hline$P m 3 c$ & 25.0 & 58.3 & 95.0 & 43.8 & 81.3 & 82.5 & 41.4 & 56.0 & 57.1 & 39.3 \\
\hline$P m 4 a$ & 50.0 & 47.2 & 95.0 & 25.0 & 87.5 & 87.5 & 58.6 & 64.0 & 67.9 & 50.0 \\
\hline$P m 4 b$ & 87.5 & 50.0 & 40.0 & 68.8 & 37.5 & 65.0 & 65.5 & 44.0 & 60.7 & 39.3 \\
\hline Pm5 & 87.5 & 75.0 & 85.0 & 31.3 & 37.5 & 95.0 & 72.4 & 72.0 & 75.0 & 60.7 \\
\hline Pm6 & 75.0 & 77.8 & 95.0 & 56.3 & 100.0 & 100.0 & 86.2 & 96.0 & 96.4 & 96.4 \\
\hline Pm7 & 75.0 & 72.2 & 100.0 & 93.8 & 100.0 & 92.5 & 69.0 & 68.0 & 71.4 & 75.0 \\
\hline $\operatorname{Pm} 8$ & 25.0 & 63.9 & 85.0 & 100.0 & 93.8 & 65.0 & 27.6 & 24.0 & 32.1 & 39.3 \\
\hline Pm17 & 12.5 & 33.3 & 25.0 & 43.8 & 50.0 & 7.5 & 13.8 & 12.0 & 7.1 & 10.7 \\
\hline$P m 1+2+9$ & 12.5 & 41.7 & 10.0 & 12.5 & 0.0 & 45.0 & 31.0 & 24.0 & 32.1 & 10.7 \\
\hline$P m 2+6$ & 0.0 & 30.6 & 10.0 & 37.5 & 31.3 & 15.0 & 17.2 & 20.0 & 17.9 & 10.7 \\
\hline$P m 5+6$ & 0.0 & 11.1 & 0.0 & 6.3 & 0.0 & 32.5 & 13.8 & 12.0 & 14.3 & 14.3 \\
\hline Mld & 37.5 & 22.2 & 0.0 & 6.3 & 0.0 & 97.5 & 82.8 & 80.0 & 71.4 & 75.0 \\
\hline$P m 5+8$ & 62.5 & 77.8 & 45.0 & 87.5 & 100.0 & 97.5 & 58.6 & 72.0 & 64.3 & 64.3 \\
\hline Mli & 75.0 & 61.1 & 35.0 & 100.0 & 81.3 & 0.0 & 34.5 & 60.0 & 46.4 & 67.9 \\
\hline$P m 2+4 b+6$ & 50.0 & 61.1 & 30.0 & 93.8 & 25.0 & 97.5 & 44.8 & 76.0 & 75.0 & 67.9 \\
\hline
\end{tabular}

Average relative virulence complexity was high in total (Table 2). The lowest relative complexity was recorded in 2001 ( 0.21 on average), and the highest in 2000 (0.81 on average).

\subsection{Relationships among Populations}

The number of common pathotypes between populations in two successive years varied from 9 (1995 and 1996, and 1998 and 1999) to 0 in most consecutive years from 2000 to 2010 (Table 6). Twenty-four common pathotypes were found in two groups, the populations of 1995-2000 and 2001-2013. 


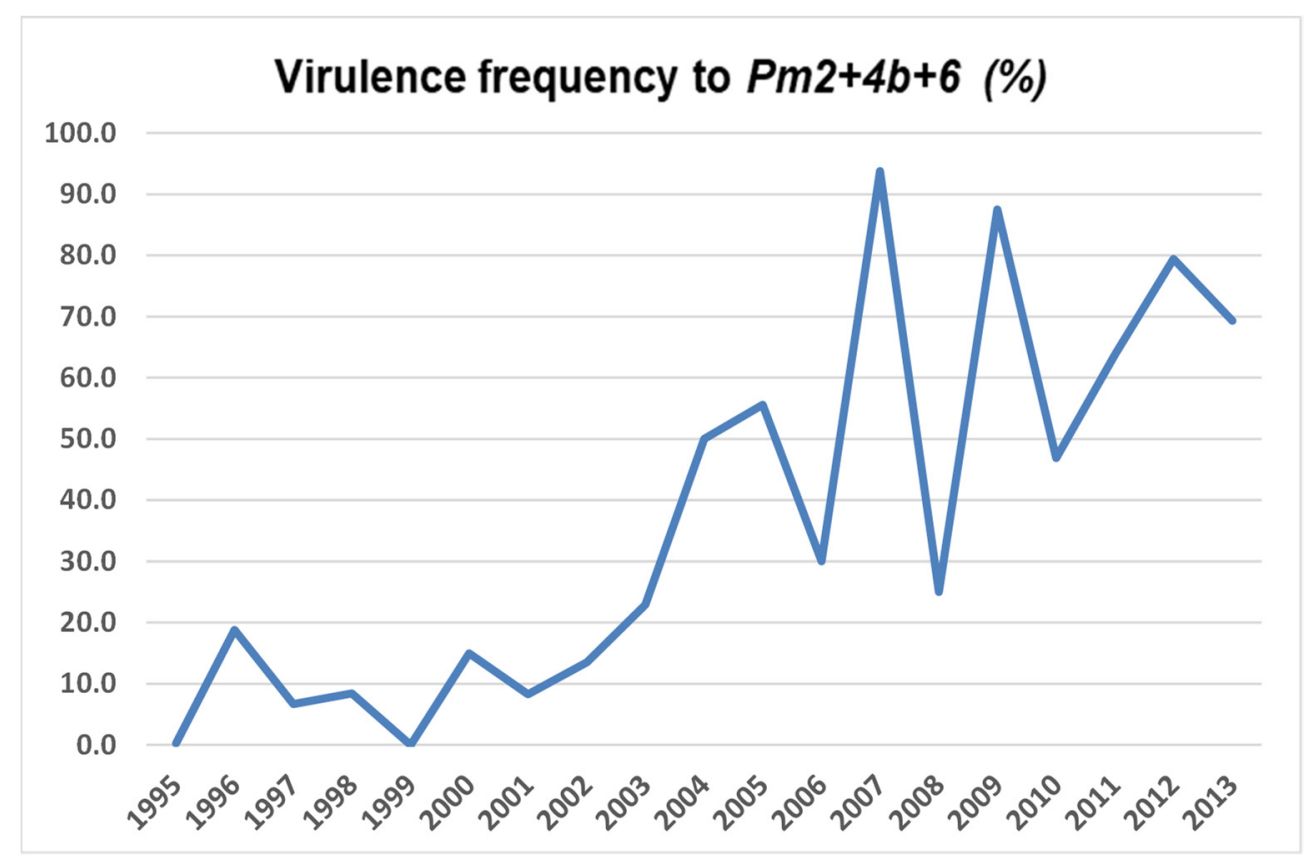

Figure 1. Virulence frequency to the gene combination $P m 2+4 b+6$ during 1995-2013.

Table 6. Distance between powdery mildew populations.

\begin{tabular}{cccc}
\hline Populations & Common Pathotypes & Rogers Distance & Nei's Gene Distance \\
\hline $1995-1996$ & 9 & 0.877 & 0.036 \\
$1996-1997$ & 4 & 0.951 & 0.056 \\
$1997-1998$ & 5 & 0.974 & 0.040 \\
$1998-1999$ & 9 & 0.941 & 0.017 \\
$1999-2000$ & 1 & 0.988 & 0.114 \\
$2000-2001$ & 0 & 1.00 & 0.749 \\
$2001-2002$ & 0 & 1.00 & 0.307 \\
$2002-2003$ & 1 & 0.981 & 0.052 \\
$2003-2004$ & 0 & 1.00 & 0.193 \\
$2004-2005$ & 0 & 1.00 & 0.094 \\
$2005-2006$ & 0 & 1.00 & 0.123 \\
$2006-2007$ & 0 & 1.00 & 0.298 \\
$2007-2008$ & 0 & 1.00 & 0.122 \\
$2008-2009$ & 0 & 1.00 & 0.302 \\
$2009-2010$ & 0 & 1.00 & 0.110 \\
$2010-2011$ & 5 & 0.828 & 0.025 \\
$2011-2012$ & 8 & 0.639 & 0.013 \\
$2012-2013$ & 6 & 0.750 & 0.034 \\
$1995-2000-2001-2013$ & 24 & 0.937 & 0.101 \\
\hline
\end{tabular}

According to the estimates of the Rogers distance, high distances were observed for most successive years (Table 6). In contrast, Nei's gene distance revealed the greatest distance only between 2000 and 2001 populations (0.749). The lowest distance was observed between the populations in 2011 and 2012 (0.013) and 1998 and 1999 (0.017).

The UPGMA dendrogram based on Nei's gene distance between the annual powdery mildew populations is shown in Figure 2. It points out two distinct clusters: the first one includes annual populations of the period 1995-2008 (except 2004) and the second of 2009-2013. 


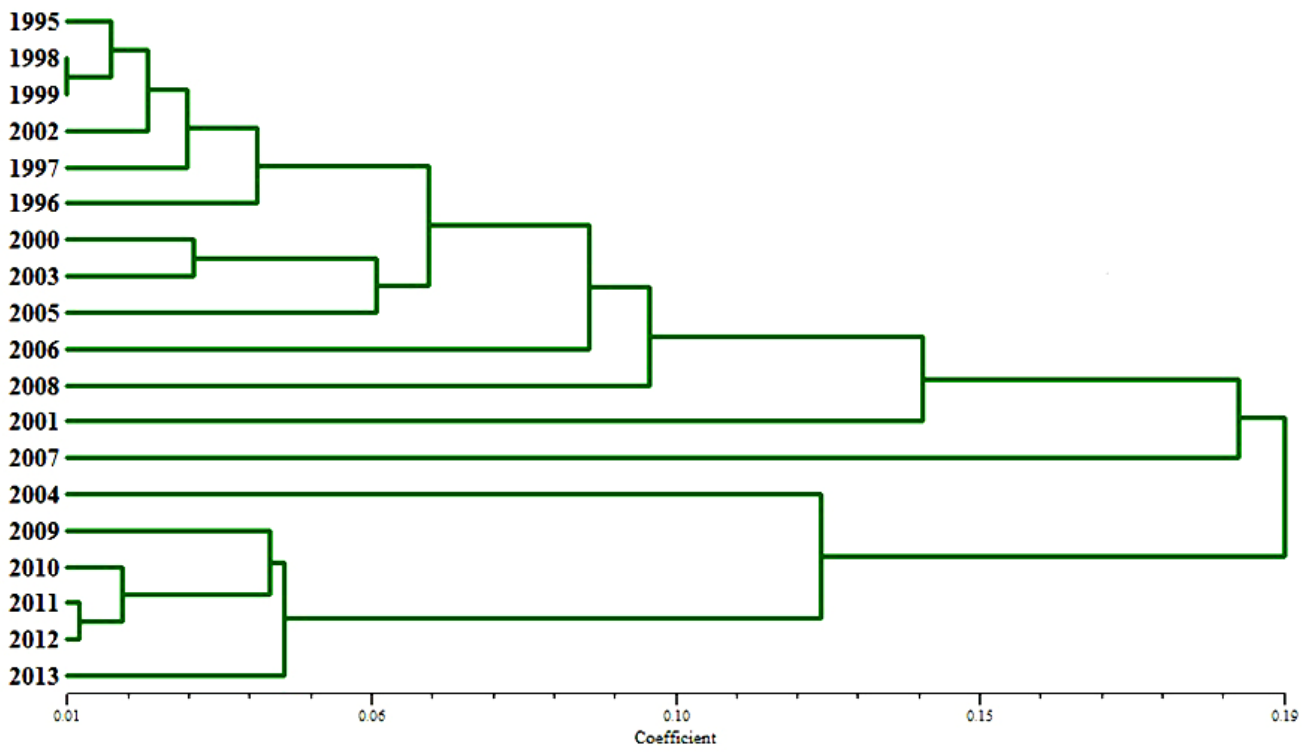

Figure 2. UPGMA dendrogram with regard to Nei's standard genetic distance between powdery mildew annual populations.

\section{Discussion}

Virulence structure of the powdery mildew population in Serbia was surveyed for the period 1995-2013. Overall, our study revealed highly diverse annual populations, with considerable differences between consecutive years. The high variability of the Serbian B. graminis f. sp. tritici population was expected due to the fact that the population structure is shaped to a large extent by sexual reproduction of the pathogen.

We found that pathotypes of this pathogen are ephemeral, changing from year to year via sexual recombination. Therefore, year-to-year comparisons of virulence gene frequencies seems to be more suitable than comparisons of pathotypes. However, some consistency when it comes to the most frequent pathotypes in the population was noticed. The most frequent was the group of TTT* ${ }^{* *}$ pathotypes, characterized by high relative virulence complexity. These pathotypes were observed mainly in the population of 1995-2000. By contrast, in the last 4 years of the survey (2010-2013), the most frequent pathotypes had lower virulence complexity. Overall, virulence complexity in total was high, and since it represents the ability of isolates to overcome multiple $P m$ genes, these results point to a large potential of the B. graminis f. sp. tritici population in Serbia to break down the resistance of local wheat varieties.

The analysis of virulence associations in terms of pathotype frequencies is especially important in the study of structural alterations in populations of plant pathogens [17]. Many associations were detected only once and mainly in the populations of 2001 and 2004, and during the period 2006-2010. These annual populations consisted of unique pathotypes (detected only once in the population) (Tables 2 and 3). Association of virulence between $M l i$ and $P m 2+4 b+6$ was frequently found (51.0\% of isolates) during the last 4 years of the study but it was not detected in the most frequent pathotypes that have been observed in this period. Additionally, association between $P m 3 b$ and $P m 4 b$ virulences was found only in the period 2009-2013, yet it was not detected in the most frequent pathotypes from this period. The high frequency of these associations accumulated from a large number of rare pathotypes carrying the corresponding virulence genes. These associations were not found in the period 1995-2003. We can assumed that significant changes that were observed in the 2010-2013 period could be explained from this strongly associated virulence. These findings are in accordance with the results of the leaf rust population survey from Israel [17], where it was concluded that some strong virulence associations could be missed if only the predominant pathotypes are considered. 
High frequency of virulence to most tested $P m$ genes was observed during the entire period of the survey. This pointed to a constant need for extending differential sets of wheat with newly identified Pm genes. The high frequency of $B$. graminis $\mathrm{f}$. sp. tritici virulent genes was also confirmed in previous studies in other countries [18-21], and recently in China [22], Ukraine [23], Australia [24], Egypt [25], Israel [26], and the USA [27].

Genes virulent to $P m 6, P m 7$, and $P m 5+8$ had constantly high frequencies. Similar results for $P m 7$ were obtained in earlier studies in the USA and Hungary [28-30]. In addition, powdery mildew monitoring in Poland [31] showed high virulence frequency to Pm5, Pm6, $P m 7$, and $P m 5+8$. Furthermore, more than $84 \%$ of the tested Chinese powdery mildew isolates were virulent to $P m 6$ and $P m 5 a$ [22].

On the other hand, combination of wheat resistance genes $P m 5+6$ remained effective in Serbia during the whole survey period. Virulence frequency to $P m 5+6$ was consistently low, leading to a conclusion that the Coker 983 line must have some additional Pm gene(s), in addition to $P m 5+6$, that is (are) more effective than this combination of genes. This conclusion was derived since the virulence frequency to $P m 5$ and $P m 6$ was intermediate or high during the whole period (with the exception of 2001). However, some increase in virulence frequency to $P m 5+6$ during the last 5 years was observed. The efficacy of combination of the resistance genes $P m 5+6$ was also detected in 1988, 1989, and 1991 in the studies of the powdery mildew population in Serbia [5,6]. However, the efficacy of the genes Pm4a,Pm4b, and Mld detected in these years has been lost since 1995, and also the efficacy of $P m 2+4 b+6$ since 2004. These results indicated the constant threat of losing resistance, presumably due to the selective pressure of varieties.

The most significant change in the B. graminis f. sp. tritici population was observed for the virulence to $P m 2+4 b+6$. This $P m$ combination was efficient for the period 1995-2002, when the corresponding virulence was at a low level ( $9.1 \%$ on average). In the period 2003-2013, the average virulence frequency increased to $58.9 \%$. Unfortunately, there is no information about $\mathrm{Pm}$ genes present in the commercial wheat varieties grown in Serbia. However, the $P m 2+4 b+6$ gene combination is present in the wheat line C39 [32], which was widely used in the wheat breeding program in Serbia. Based on these results, it can be presumed that the selective pressure of commercial wheat varieties led to the change in virulence to $P m 2+4 b+6$.

The Simpson's index showed a high phenotypic diversity within annual powdery mildew populations during 19 years. However, according to the Kosman index, high diversity was observed in populations of 2005 and during the last 4 years of the survey. The same issue of inconsistency was noticed when distance between populations was measured by different metrics. According to the Rogers index, distances between most successive years were very large (around the theoretical maximum 1), while the corresponding values of Nei's distances were relatively small, with the greatest distance between 2000 and 2001 populations. Weak correlation between estimates obtained with different diversity/distance indices was already observed and demonstrated [10]. This inconsistency can be attributed to the nature of these indices: the Simpson's index and Rogers distance are based only on pathotype frequencies in the population. On the other hand, Nei's gene distance is based on virulence frequencies, whereas the Kosman index uses dissimilarity between isolates and maximizes the overall dissimilarity within a population. Similar discrepancy between estimates of different types was also shown in the study of powdery mildew population originated from barley [33].

The Rogers index showed a high dissimilarity between populations in the two periods: 1995-2000 and 2001-2013, with only 24 common pathotypes out of 1013 tested isolates. However, clustering of years using Nei's standard gene distance dissimilarity between B. graminis f. sp. tritici annual populations was detected between 1995-2008 (except 2004) and 2009-2013. These findings also indicate that there was a shift in the virulence structure of the powdery mildew population over the years.

Our results revealed that in the last period of the survey (2010-2013), the B. graminis f. sp. tritici population changed remarkably (the most frequent pathotypes, pairwise 
virulence associations, and also virulence frequency and complexity). This can be attributed to changes in wheat varieties grown in Serbia during the period 2000-2010. Although there is no information on the genetic background of the newly introduced varieties, one can assume that the variety shifts might have an influence on the pathogen as a result of the selection pressure.

\section{Conclusions}

Powdery mildew surveys that took place over a long period of time provided data of great importance for keeping track of the change in virulence occurring in powdery mildew populations and planning wheat breeding program strategies.

The obtained results showed that the virulence structure of the powdery mildew population in Serbia is complex and highly diverse. Furthermore, these results suggested that disease resistance can easily be overcome by the pathogen, resulting in severe epidemics in years with favorable agro-climatic conditions.

The gene combination $P m 5+6$ has remained effective during the whole period of the survey. Therefore, the Coker 983 wheat line possessing these resistance genes should be used in wheat breeding programs for resistance to powdery mildew. Nevertheless, introduction of new wheat lines with $P m$ resistance genes is necessary for further research on powdery mildew populations in Serbia and also for possible incorporation of these genes into wheat breeding material.

Author Contributions: Conceptualization, R.J. and M.L.; methodology, R.J. and M.L.; validation, R.J. and S.M.; formal analysis, M.L. and V.Ž.; investigation, R.J. and M.L.; resources, R.J. and M.L.; data curation, M.L. and B.O.; writing-original draft preparation, M.L.; writing—review and editing, R.J. and V.Ž.; visualization, M.L. and R.J.; supervision, R.J. and S.M.; project administration, R.J. and M.L.; funding acquisition, R.J. All authors have read and agreed to the published version of the manuscript.

Funding: This research was funded by the Ministry of Education, Science and Technological Development of the Republic of Serbia, grant number: 451-03-9/2021-14/200032.

Institutional Review Board Statement: Not applicable.

Informed Consent Statement: Not applicable.

Data Availability Statement: Data are available upon request from the corresponding author.

Conflicts of Interest: The authors declare no conflict of interest.

\section{References}

1. Jevtić, R.; Župunski, V.; Lalošević, M.; Župunski, L. Predicting potential winter wheat yield losses caused by multiple disease systems and climatic conditions. Crop Prot. 2017, 99, 17-25. [CrossRef]

2. McDonald, B.A.; Linde, C. The population genetics of plant pathogens and breeding strategies for durable resistance. Euphytica 2002, 124, 163-180. [CrossRef]

3. Heun, M. Virulence frequencies influenced by host resistance in the host-pathogen system wheat-powdery mildew. J. Phytopathol. 1987, 118, 363-366. [CrossRef]

4. Smiljaković, H. Physiological specialization in Erysiphe graminis tritici in Serbia. Savrem. Poljopr. 1966, 1, $357-363$.

5. Stojanović, S.; Stojanović, J.; Jevtić, R.; Pribaković, M. Virulence of the Erysiphe graminis DC. ex Merat f. sp. tritici Em. Marchal genotypes proliferated by sexual reproduction. Zaštita Bilja 1991, 195, 7-19.

6. Jevtić, R. Struktura virulentnosti polne i bespolne populacije Erysiphe graminis tritici. Ph.D. Thesis, Univerzitet u Novom Sadu, Poljoprivredni fakultet, Novi Sad, 1993.

7. Mains, E.B. Inheritance of resistance to powdery mildew, Erysiphe graminis tritici, in wheat. Phytopathology 1934, $24,1257-1261$.

8. Flor, A.H. Host-parasite interactions in flax rust-its genetics and other implications. Phytopathology 1955, 45, 680-685.

9. Schachtel, G.A.; Dinoor, A.; Herrmann, A.; Kosman, E. Comprehensive evaluation of virulence and resistance data: A new analysis tool. Plant Dis. 2012, 96, 1060-1063. [CrossRef]

10. Kosman, E.; Leonard, K.J. Conceptual analysis of methods applied to assessment of diversity within and distance between populations with asexual or mixed mode of reproduction. New Phytol. 2007, 174, 683-696. [CrossRef]

11. Nei, M. Genetic distance between populations. Am. Nat. 1972, 106, 283-292. [CrossRef]

12. Sokal, R.R.; Rohlf, F.J. Biometry; W. H. Freeman: New York, NY, USA, 1995. 
13. Kosman, E. Measure of multilocus correlation as a new parameter for study of plant pathogen populations. Phytopathology 2003, 93, 1464-1470. [CrossRef]

14. Kosman, E.; Dinoor, A.; Herrmann, A.; Schachtel, G.A. Virulence Analysis Tool (VAT). User Manual. 2008. Available online: http://www.tau.ac.il/lifesci/departments/plant_s/members/kosman/VAT.html (accessed on 1 December 2021).

15. Felsenstein, F.G.; Jaser, B. Effectiveness of Qualitative Powdery Mildew Resistance in Wheat and Barley and Sensitivity of Fungal Cereal Pathogens towards Different Compounds. 2000. Available online: http:/ / www.epilogic.de/eng/BL\%202000\%20Bericht\% 20engl.htm (accessed on 20 July 2021).

16. Rohlf, F.J. NTSYS-pc: Numerical Taxonomy and Multivariate Analysis System, version 2.1.; Exeter Software Setauket: New York, NY, USA, 2000.

17. Kosman, E.; Ben-Yehuda, P.; Manisterski, J. Diversity of virulence phenotypes among annual populations of wheat leaf rust in Israel from 1993 to 2008. Plant Pathol. 2014, 63, 563-571. [CrossRef]

18. Menzies, J.G.; Macneisll, B.H.; Gang, P. Virulence spectrum of Erysiphe graminis f. sp. tritici in southern Ontario in 1986 and 1987. Can. J. Plant Pathol. 1989, 11, 338-341. [CrossRef]

19. Imani, Y.; Ouassou, A.; Griffey, C.A. Virulence of Blumeria graminis f. sp. tritici populations in Morocco. Plant Dis. 2002, 86, 383-388. [CrossRef] [PubMed]

20. Inuma, T.; Khodaparast, S.A.; Takamatsu, S. Multilocus phylogenic analyses within Blumeria graminis, a powdery mildew fungi of cereals. Mol. Phylogenet. Evol. 2007, 44, 741-751. [CrossRef] [PubMed]

21. Wakulinski, W.; Zamorski, C.Z.; Nowicki, B. Podatnosc odmian i linii hodowlanych pszenzyta na porazenie przez Blumeria graminis (DC) Speer. Prog. Plant Prot. 2007, 47, 361-365.

22. Zeng, F.S.; Yang, L.J.; Gong, S.J.; Shi, W.Q.; Zhang, X.J.; Wang, H.; Xiang, L.B.; Xue, M.F.; Yu, D.Z. Virulence and diversity of Blumeria graminis f. sp. tritici populations in China. J. Integr. Agric. 2014, 13, 2424-2437. [CrossRef]

23. Babayants, O.V.; Babayants, L.T.; Traskovetskaya, V.A.; Gorash, A.F.; Saulyak, N.I.; Galaev, A.V. Race composition of Blumeria graminis (DC) Speer f. sp. tritici in the south of Ukraine and effectiveness of Pm-genes in 2004-2013. Cereal Res. Commun. 2015, 43, 449-458. [CrossRef]

24. Golzar, H.; Shankar, M.; D'Antuono, M. Responses of commercial wheat varieties and differential lines to western Australian powdery mildew (Blumeria graminis f. sp. tritici) populations. Australas. Plant Pathol. 2016, 45, 347-355. [CrossRef]

25. El-Shamy, M.M.; Emara, M.H.; Mohamed, E.M. Virulence Analysis of Wheat Powdery Mildew (Blumeria graminis f. sp. tritici) and Effective Genes in Middle Delta, Egypt. Plant Dis. 2014, 100, 1927-1930. [CrossRef]

26. Ben-David, R.; Parks, R.; Dinoor, A.; Kosman, E.; Wicker, T.; Keller, B.; Cowger, C. Differentiation among Blumeria graminis f. sp. tritici isolates originating from wild vs. domesticated Triticum species in Israel. Phytopathology 2016, 106, 862-870. [CrossRef] [PubMed]

27. Cowger, C.; Mehra, L.; Arellano, C.; Meyers, E.; Murphy, J.P. Virulence differences in Blumeria graminis f. sp. tritici from the central and eastern United States. Phytopathology 2018, 108, 402-411. [CrossRef] [PubMed]

28. Niewoehner, A.S.; Leath, S. Virulence of Blumeria graminis f. sp. tritici on winter wheat in the eastern United States. Plant Dis. 1998, 82, 64-68. [CrossRef]

29. Parks, R.; Carbone, I.; Murphy, J.P.; Marshall, D.; Cowger, C. Virulence structure of the eastern U.S. wheat powdery mildew population. Plant Dis. 2008, 92, 1074-1082. [CrossRef]

30. Szunics, L.; Szunics, L. Wheat powdery mildew resistance genes and their application in practice. Acta Agron. Hung. 1999, 47, 69-89.

31. Czembor, H.J.; Domeradzka, O.; Czembor, J.H.; Mankowski, D.R. Virulence structure of the powdery mildew (Blumeria graminis) population occurring on triticale (xTriticosecale) in Poland. J Phytopathol. 2014, 162, 499-512. [CrossRef]

32. Chung, Y.S.; Griffey, C.A. Powdery mildew resistance in winter wheat: II. Identification of resistance genes. Crop Sci. 1995, 35, 383-388. [CrossRef]

33. Dreiseitl, A.; Dinoor, A.; Kosman, E. Virulence and diversity of Blumeria graminis f.sp. hordei in Israel and in the Czech Republic. Plant Dis. 2006, 90, 1031-1038. [CrossRef] [PubMed] 